Romanticism on the Net

An open access journal devoted to British Romantic literature

Ro Romanticism on the Net

\title{
Prosaic Poetry and Pneumatic Craving in Southey's Curse of Kehama
}

\section{Adam Colman}

Numéro 68-69, spring-fall 2017

Robert Southey

URI : https://id.erudit.org/iderudit/1070623ar

DOI : https://doi.org/10.7202/1070623ar

Aller au sommaire du numéro

Éditeur(s)

Université de Montréal

ISSN

2563-2582 (numérique)

Découvrir la revue

Citer cet article

Colman, A. (2017). Prosaic Poetry and Pneumatic Craving in Southey's Curse of Kehama. Romanticism on the Net, (68-69). https://doi.org/10.7202/1070623ar

\section{Résumé de l'article}

Among those affiliated with Thomas Beddoes's Pneumatic Institution in Bristol, there were a number who poetically emphasized the hopeful attributes of scientific pursuit. Coleridge did so; Humphry Davy did in his poetry, too; Robert Southey had early on asserted the connection between scientific study and hope. Southey, however, would remark that he had undergone especially volatile responses to nitrous oxide. His sense of adventures through a material world would, in the years following his time spent at the Pneumatic Institution, become conflicted. He would, in particular, register pneumatically inflected hopes in less idealistic terms than Coleridge or Davy. Instead, Southey's poetry has passages containing descriptions of pneumatic desires in terms of anguished bodily craving. This essay considers how Southey's Curse of Kehama, published in 1810, locates an especially vexed sense of bodily craving in the kind of thinking about matter and air associated with the Pneumatic Institution. I examine how such physically wrenching desire relates to the form of Southey's poem, wherein certain poetic rhythms of anticipation-iterations suggesting others still to come-operate within a more prosaic realm of conflicted, irregularly interconnected, material immanence. 


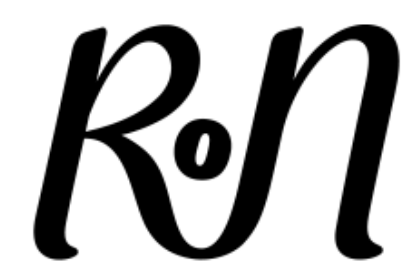

\title{
Romanticism on the Net
}

\section{Prosaic Poetry and Pneumatic Craving in Southey's Curse of Kehama}

Adam Colman

University of Massachusetts Amherst

\begin{abstract}
Among those affiliated with Thomas Beddoes's Pneumatic Institution in Bristol, there were a number who poetically emphasized the hopeful attributes of scientific pursuit. Coleridge did so; Humphry Davy did in his poetry, too; Robert Southey had early on asserted the connection between scientific study and hope. Southey, however, would remark that he had undergone especially volatile responses to nitrous oxide. His sense of adventures through a material world would, in the years following his time spent at the Pneumatic Institution, become conflicted. He would, in particular, register pneumatically inflected hopes in less idealistic terms than Coleridge or Davy. Instead, Southey's poetry has passages containing descriptions of pneumatic desires in terms of anguished bodily craving. This essay considers how Southey's Curse of Kehama, published in 1810, locates an especially vexed sense of bodily craving in the kind of thinking about matter and air associated with the Pneumatic Institution. I examine how such physically wrenching desire relates to the form of Southey's poem, wherein certain poetic rhythms of anticipation-iterations suggesting others still to come-operate within a more prosaic realm of conflicted, irregularly interconnected, material immanence.
\end{abstract}

Biographical Note

Adam Colman is a lecturer at the University of Massachusetts Amherst. His work has appeared in European Romantic Review and Extrapolation. 


\section{Romanticism on the Net \#68-69 (Spring-Fall 2017). Special issue on Robert Southey. Guest-edited by Tim Fulford (De Montfort University) and Matthew Sangster (University of Glasgow)}

1. In 1799 and 1800, work at Bristol's Pneumatic Institution suggested a range of poetic possibilities. Following his Bristol encounters with pneumatic experiment, Coleridge would insist that science was "poetical" in a January 1, 1800, letter to Humphry Davy, specifically because science related to "the passion of hope" (Letters 1 557). In the case of Robert Southey, on the other hand, pneumatic chemistry's new sense of air-and matter, more generally-did not so simply maintain hope. A related, more materially vexed craving instead emerged in Southey's letters and poetry. This essay considers how Southey's Curse of Kehama locates such craving in the kind of anticipatory thinking about matter and air associated with the Pneumatic Institution. That sort of physical desire, in a world defined by interlinked matter, also pertains to the form of Southey's epic poem set in India, a poem whose rhythms of recurrent craving operate within a prosaic realm of expansively interconnected, material immanence. In short, this essay argues that experiences with pneumatic chemistry influenced Southey's development of a prosaic poetry, a style characterized by anticipatory rhythms amid discursive representations of material interconnection. ${ }^{1}$

2. Prominent pneumatic chemists would also point toward a connection between the prosaic and the poetic sense of anticipated recurrences. Consider, for example, the various versions of Humphry Davy's poem, "Life of a Spinosist," starting from 1800. There, mundane and interconnected matter mixes with poetic thoughts of abstract spirits and futurity. In a version of the poem retitled "Written After Recovery from A Dangerous Illness," we read of how "o'er the earth the kindling spirits pour / The flames of life that bounteous Nature gives; / The limpid dew becomes the rosy flower" (John Davy 114). In a revised version of the poem that appeared in 1823, titled "Life," the poem's speaker contemplates a still more abstract and vague sense of futurity, hoping,

To dwell upon utility alone,

As the true source of honour, to aspire

To something which posterity may own,

A guiding lamp, not a consuming fire... (Baillie 161)

The closing lines of Davy's "Life" poem call for a sustained dissatisfaction found in scientific learning, an endless pursuit of an idealized state where one might "bask in the eternal Fount of light, / With hope amidst fruition still to burn / In the unsated love of knowledge infinite" (Baillie 162). Contemplation of matter has driven the speaker to think of orientation toward the future; Davy thus uses language of satiety and its lack to describe the pursuit of knowledge in 


\section{Romanticism on the Net \#68-69 (Spring-Fall 2017). Special issue on Robert Southey. Guest-edited by Tim Fulford (De Montfort University) and Matthew Sangster (University of Glasgow)}

the material world. There is a particular theological mood to this later version of the poem, as Sharon Ruston notes, writing, "The 'Life' poem is less concerned with matter changing into other forms"; instead of an adherence to Priestleyan or Spinozan interconnection, it seems, Ruston writes, that "Life" combines "Platonism with Christianity" (90-91). Still, such theological ideas coexist with the poem's interest in ambitious acquisition of knowledge, characterized by a sense of hope that can recur infinitely as one continually pursues knowledge in material reality.

3. Coleridge, again, told Davy in 1800 that he saw science aligned with poetry because both dealt with hope, and Davy expresses something like that hope in the "Life" poem and its antecedents. Even in the earlier version titled "Written After Recovery From a Dangerous Illness," after Davy describes "the skies with morning radiance bright, / Majestic mingling with the ocean blue," he also describes a "heavenly balm of mutual hope" and "affection's bliss," which is "[s]weet as the stream amidst the desert waste" (John Davy 115). A sense of things for which we should hope, found within the material world of ongoing, intermingling process, structures a poetic orientation toward something beyond material immediacy. It is in the later version of Davy's poem, when the anticipation intensifies, that Davy describes aspiring, "unsated," to “something which posterity may own." In any case, Davy's evolving poem charts links between the hopeful, craving mind and prosaic matter, yet often that very hopefulness leads thought beyond the materially immanent. Hope inevitably calls upon at least two temporal levels: now and later. It establishes or requires temporal distinctions, which can complicate a harmonious relationship between the mind's projections and what materially exists, and Davy's closing scientific-religious sense of craving and insatiability in the "Life" poem suggests such complication.

4. Southey would attend to still more discomfiting experience of materiality. In an 1808 letter to Coleridge, Southey expressed the confused reactions to physical phenomena he observed in himself, which he understood in light of his nitrous oxide experiences at the Pneumatic Institution. He prefaced this discussion by appealing to Coleridge's love of science; here, however, that love of science is called upon to train itself on the "odd," on "peculiarities," on that which does not make perfect sense:

You love the science of physic [Southey wrote to Coleridge] ... I will tell you, therefore, two odd peculiarities of my constitution; the slightest dose of laudanum 


\section{Romanticism on the Net \#68-69 (Spring-Fall 2017). Special issue on Robert Southey. Guest-edited by Tim Fulford (De Montfort University) and Matthew Sangster (University of Glasgow)}

acts upon me as an aperient; - if I am at any time exposed to the sun bareheaded for two minutes, I infallibly take cold. This probably shows how soon I should be subject to a stroke of the sun, and indicates the same over-susceptibility which the nitrous oxide did, a smaller dose affecting me than any other person who ever breathed it. (CLRS 1466)

At the Pneumatic Institution, Southey's experiences were especially varied-occasionally pleasing, occasionally alarming. On the one hand, he reported to his brother of nitrous oxide, "it made me laugh \& tingle in every toe \& finger tip. Davy has actually invented a new pleasure for which language has no name. oh Tom! I am going for more this evening - it makes one strong \& so happy! so gloriously happy" (CLRS 421). Later, however, Southey would remark to Charles Watkin Williams Wynn that "the gas now always affects my respiration-it becomes as you saw excessively quick \& short" (CLRS 509). This recognition of material variability and uncertainty occurred under the guidance of men of science who had described their work as a radically hopeful enterprise, as Davy's poetry suggests and as Davy's reform-minded forebears Thomas Beddoes and Joseph Priestley made clear. The link between the work of the pneumatic chemists and hope was such that when Beddoes died, Coleridge wrote that "more Hope had been taken out of my life by this than by any former Event" (Letters 3 171; qtd. in Levere 63). ${ }^{2}$ But, as Southey notes, the experience of nitrous oxide inhalation was in his case peculiar and not wholly hope-inspiring, due to his "over-susceptibility" to the gas's effects-something singular and discontinuous was introduced to a previously smoothly hopeful understanding of science and experimental adventures.

5. Southey registered a more troubling sense of the relationship between mind and matter. This sense developed from Southey's recognition of something rather less than philosophical: his own private reactions to matter, which were, in the case of his experiences with pneumatic chemistry, different from those of others. The link between matter and the realm of the ideal had come to seem especially lodged within the self, within one's own peculiar sensibilities and desires. Southey himself referred to his experiences with nitrous oxide to explain his shift toward a more alarmed understanding of broader material conditions. In a letter to Josiah Conder from July 5, 1815, Southey writes, "You ask me upon what grounds I apprehend that all established institutions are in danger," and he then turns to the example of his nitrous-oxide use to describe an associated feeling of destabilizing revolution: 
You are not old enough to remember the morning of the French Revolution, and the delirious effect it produced upon generous and inexperienced minds. Did you ever inhale the nitrous oxide? We seemed to be living in such an atmosphere. (CLRS 2632) Material circumstances, whether those of social institutions or personal physiological experience, contributed to affective experience that inclined one toward the future-perhaps deliriously so, depending on the nature of those circumstances. Nitrous oxide inhalation and the French Revolution alike generated material, atmospheric circumstances that could lead one woozily, bewilderingly into the future. Southey had evidently found in pneumatic, materialist studies a language for articulating his relationship with revolutionary volatility - a language similarly accessed by Edmund Burke, for instance, in Reflections on the Revolution in France (for more on the discussions of revolution with regard to pneumatic chemistry, see Jay 4). This sense of a widely relevant material instability underwrote, for Southey, dramas of dissatisfaction, of craving, of yearning for something better that has yet to be. He would describe craving that was part of a complicated network of material and social intersections, recounting, for instance, how he came to find that "manufactures occasioned a sudden increase of craving mouths" (CLRS 2231).

6. In The Curse of Kehama in particular, Southey produced a poetic and intensified articulation of this sense of craving embedded in uncomfortable material experience. The result is a poem of rhythmic patterns and jagged prosaic form, a poem of unstable material resonance and poetically recurrent anticipations of something still to come. Southey wrote in a letter to Walter Savage Landor from May 20, 1808, that The Curse of Kehama was to be a poem marked by "quicker-wilder movements" and irregular rhyming: "rhyme must be scattered upon rhyme till the reader is half dozing with the thundering echo" (CLRS 1459). Here we see Southey relating irregular rhythm to the material nature of the poem, its relationship to atmospheric thundering. Rhythmic repetitions and the wildly scattered - the arrhythmic — were to combine; poetry was to link to prose for this writer who saw the mysteriously expansive material world linked with intoxicating power to the individual mind.

\section{Southey's Intellectual and Formal Contradictions}

7. The collision of different aesthetic qualities and opposed perspectives in Southey's work has long drawn attention. Nigel Leask writes that The Curse of Kehama "is characteristically 


\section{Romanticism on the Net \#68-69 (Spring-Fall 2017). Special issue on Robert Southey. Guest-edited by Tim Fulford (De Montfort University) and Matthew Sangster (University of Glasgow)}

ambivalent in its ideological bearings," appealing to radical readers such as Percy Shelley as well as to imperialist readings (96). Tim Fulford has described Southey's efforts to link and critique Asia and Jacobinical forces in order "to try to distance himself from the movements with which he was most associated" (129). The dynamics of Southey's work have also been read as expressions of colliding ways of thinking within British Romanticism. Balachandra Rajan summarizes how imperialism meets with academic poetry in The Curse of Kehama: "The Romantic oeuvre ... is begotten by desire upon impossibility. For Southey, the child of impossibility is an unprecedented exercise in comparative mythology" that works "amid the widening horizons of Romantic thought. It is an academic poet's dream of empire" (204).

8. The Curse of Kehama demonstrates how the "dream of empire" Rajan observes could relate to certain kinds of study in which Southey participated. We can see there, for instance, orientalist studies tied to Southey's consideration of atmospheric, pneumatic conditions. In one of his notes to The Curse of Kehama, Southey cites a British writer on wind in India-specifically quoting William Hodges's Travels in India:

it is not uncommon, towards the evening, to see a small black cloud rising in the eastern part of the horizon, and afterwards spreading itself to the north-west. This phenomenon is always attended with a violent storm of wind, and flashes of the strongest and most vivid lightning and heavy thunder, which is followed by rain. (EPW 201-202)

The lines in The Curse of Kehama that Southey glosses with the Hodges quote (V.34-36) do not simply depict the intensely "vivid" and "heavy" changes that Hodges describes. Instead, Southey has given the following description:

The Moon is up, still pale

Amid the lingering light.

A cloud ascending in the eastern sky,

Sails slowly o'er the vale,

And darkens round and closes-in the night. (V.32-36)

Here, material phenomena seem to foreclose steadier knowledge, as the sky circumscribes the character Ladurlad. There is more to know and to seek, but immediate perception has been limited by the night, and so Southey's studiously attentive reader is prompted to look to the poet's annotations, where the reader finds the British description of an Indian atmosphere. Expansive prose elaborates on the intimations of the poetry, which is limited to certain material 


\section{Romanticism on the Net \#68-69 (Spring-Fall 2017). Special issue on Robert Southey. Guest-edited by Tim Fulford (De Montfort University) and Matthew Sangster (University of Glasgow)}

conditions while continually suggesting more to come in some future, rhythmic iteration. Studious, repetitive attention to such matter leads, then, further into a pneumatic and orientalist atmosphere of mystery.

9. There is throughout The Curse of Kehama a clear material link between repetition and this movement toward mystery-between that which may be rationally patterned and that which remains beyond such patterns. Southey would elsewhere associate the effects of repeated rhyme in The Curse of Kehama with an orientalist and atmospheric sense of a material world suggestive of more beyond immediate or familiar experience. In the already-quoted letter to Walter Savage Landor from May 20, 1808, Southey wrote that his poetic plans for The Curse of Kehama (including those "wilder movements") were to involve "gorgeousness of ornament also, - eastern gem work" along with rhyme that "must be scattered upon rhyme" until "the reader is half dozing with the thundering echo" (CLRS 1459). Here orientalist details, the wilder rhythms, and the scattered "rhyme upon rhyme" do similar work, in Southey's estimation: they make the reader dreamily dazed, dizzy, distracted, and overwhelmed by atmospheric echoes from an actual world that extends beyond the repetitively familiar. The mood of orientalismthe wish for eastern gems - matches the sense of a dazzlingly atmospheric, thunderously material world. Poetic, sonic repetitions can, Southey suggests in this letter, generate a sensibility like both atmospheric experience and orientalist thought, all of which leads from often repetitive material experience and into confusion-into, in Southey's words, a "half dozing state."

10. Southey's ideas about India, material existence, and poetry are typically ambiguous. India becomes associated with both the appealing (rich with "eastern gem work") and that which confounds; the materials of weather and atmosphere and thundering echoes are all actual and familiar phenomena while nonetheless promising further volatility and mystification; and poetry produces steady rhythms that lead beyond lucid understanding, pointing toward future iterations yet to be fully grasped. At the heart of all these contradictions in The Curse of Kehama is a particular sense of repetitive, persistent hopes that lead through interrelated material contexts and toward uncertainty, recurrent hopes that contradictorily link material actuality with that which has yet to be. 
11. The Curse of Kehama thus develops formal contradictions that further develop Southey's intellectual contradictions. Rajan considers such contradictions in the poem particularly with regard to Southey's prefaces and their imperialist views versus the less politically fixed poem itself. Rajan writes, "The relationship between the rebellious poem and the reprimanding prefaces ... lays bare with a clarity which may be unique, the quarrel between the ideological and poetic selves, between containment and proliferation, between regulatory reason and inventive fancy" (213). This collision between imperial and rebellious language, which Rajan associates with a collision between regulatory reason and inventive fancy, relates to contradictions registered throughout Southey's writing. Dahlia Porter has shown how a broader "interplay between verse and note" encourages questions and disrupts the empiricist, imperialist agenda outlined in the preface of Thalaba the Destroyer (675-676). Fulford describes another example of these contradictions: Southey's critique of millenarian thought and his alarmed sense that rational study has led to irrational experience. Writing about the millenarian pamphleteer Nathaniel Halhed, Southey describes how Halhed's "study of Indian mythology" led to "a strange perversion of the intellect" (Letters from England 223; see also Fulford 125). For Southey, as Fulford puts it, Halhed "had lost his ability to judge where the proper limits of rational enquiry lay" following his "logical research into prophetic and miraculous claims" (127). Southey saw in studies of India the potential for inquiry that would undermine itself. A related, vexed sense of mental endeavor makes itself apparent in Southey's language about pneumatic or more generally material experience. The development of such language gave a new dimension to Southey's earlier senses of idealist, inventive fancy and the powers of the mind.

\section{Southey's Idealist Hopes}

12. Well before he began materialist self-experimentation in Bristol with hopeful chemists such as Davy and Beddoes, Southey was thinking about links between hope and vitality. In a 1794 letter to his brother outlining their Pantisocratic plan to create a commune in the United States, Southey wrote that "this Pantisocratic system has given me new life new hope new energy. all the faculties of my mind are dilated - I am weeding out the few lurking prejudices of habit \& looking forward to happiness" (CLRS 106). This is a hope that accompanies "new life"-it seems rich with Romantic vitalism. Yet the home of the "new energy" suggested by hope is in 
Romanticism on the Net \#68-69 (Spring-Fall 2017). Special issue on Robert Southey. Guest-edited by Tim Fulford (De Montfort University) and Matthew Sangster (University of Glasgow)

"all the faculties of [Southey's] mind"-hope here lives comfortably in the realm of the ideal, of the imagination.

13. Earlier, in a 1792 letter to Grosvenor Charles Bedford, Southey had described hope similarly involved in a drama of mental faculties and emotions-hope was incapable of acquiring "happiness or rest" from the "sullen tyrant" of melancholy, and required the vehicle of "energic prayr" to coast "beyond Despair" (CLRS 16). In these early letters we encounter an immaterial, psychological hope, which repeatedly relates to mental energy without so often engaging the realm of matter. In November 1793 Southey included in a letter to Horace Walpole Bedford his poem that bids "Farewell to Hope" precisely because hope is "weak" compared to "Apathys cold shore" (CLRS 66). Here a material sense of something beyond usual emotions - the cold shore of apathy — seems sturdy, mightier than hope precisely because it suggests the solidity of material outside of emotions.

14. Still, in a 1793 letter to Bedford, Southey was also making the connections between science and hope that Coleridge would express in his letter to Davy. If hopes were thwarted by material reality, they could at least, it seemed, lead to greater knowledge of that material reality. We see this, for example, in these lines that would later be published under the title "To Lycon":

Yet on the summit of yon craggy steep

Hope stands surrounded with a blaze of light -

She bids the wretch no more despondent weep

Or linger in the loathly realms of night,

And Science comes celestial maid

As mild as good she comes to aid

To smooth the rugged steep with magic power

And fill with many a wile the longly-lingering hour. (CLRS 72)

Amid a wasteland of bad feelings, personified Hope presents a compelling case against despondency, in clear terms of light versus darkness, and Science arrives in similar language, linked to the "celestial," to the summit-standing, blazing light of Hope. Both Hope and Science offer a mental reconfiguration of space and time, too: Science can "fill with many a wile the longly-lingering hour" and "smooth the rugged steep with magic power," while Hope's "blaze of light" leads the wretch away from "the loathly realms of night." Once again, however, the effects of such hopeful science are primarily within the mind-it alters mood, and it alters the 


\section{Romanticism on the Net \#68-69 (Spring-Fall 2017). Special issue on Robert Southey. Guest-edited by Tim Fulford (De Montfort University) and Matthew Sangster (University of Glasgow)}

attitude toward time and space, but it seems to come from a lofty source to alter such moods, rather than from the material realm.

15. In the same 1793 letter to Horace Walpole Bedford, Southey describes abstractions' effects on mood and social experience at greater length. He considers "how very depraved is society," which, "by making artificial distinctions ... creates real misery — by aggrandizing the few oppresses the many" (CLRS 72). Artifice could, for the radical Southey of the 1790s, shape material, social conditions. But the movement between abstraction, artifice, and material reality at this radically idealistic stage of Southey's career occurs largely in one direction-from the abstract to the material—and far more directly than it would in Southey's later work.

16. In letters from the early days of Southey's contemplation of the Pantisocratic scheme, we find evidence of a radical sense of communally linked desire that addressed futurity with an idealist's sense of union between oneself and everything else. He wrote to Grosvenor Charles Bedford in 1794, "my mind is full of Futurity — \& lovely is the prospect" (CLRS 108). Southey used language of desire to describe this mind full of futurity, but it is a sense of a futurity in which one's self and everyone else might come together: "I am exalted in my own eyes — I am of consequence to others - Life is desireable to me" (CLRS 108). One's own thoughtsprivate considerations of exaltation at oneself - could be joined with others, all of which was desired and imagined to come to fruition in the future.

17. It is not as if Southey, before his experiences at the Pneumatic Institution, could not imagine a more dramatically tense struggle between mind, or one's internal self, and the rest of the world. In his reading of Rousseau's Confessions, which he described in a letter from 1798, Southey noted "a perpetual struggle between his soul \& body" (CLRS 303). This struggle, Southey wrote, set the terms for Rousseau's "cravings of a heart that wanted \& deserved an equal companion, \& which when plunging into sensuality felt its own degradation $\&$ the emptiness of sensual enjoyment” (CLRS 303). We see here anticipations of Southey's later sense of unstable and varied physical situations; of the Confessions, Southey notes, "as the mind that receives it is healthy or diseased it becomes medicinal or poisonous" (CLRS 303). Southey had, in other words, developed some understanding of mind and matter struggling together, altering one another and thereby informing the experience of craving and yearning for futurity. Still, in these years he maintained ideals of radical union, and even in his response to Rousseau's Confessions 


\section{Romanticism on the Net \#68-69 (Spring-Fall 2017). Special issue on Robert Southey. Guest-edited by}

Tim Fulford (De Montfort University) and Matthew Sangster (University of Glasgow)

he notes something like that union occurring through "feelings of regret \& compassion" inspired by Rousseau's narration of his struggles (CLRS 303). A sense of people suffering together, despite their differences and physical peculiarities, thus characterizes Southey's reading of Rousseau's solitary, uniquely embodied struggling. The response of readers then fulfills those "cravings of a heart that wanted \& deserved an equal companion," those cravings Southey identified in the voice of Rousseau's text. An ideal, desired social organization could thus be imagined into existence by a work of literature.

18. And so, again, Southey's early letters reveal a rather straightforwardly idealistic, Pantisocratic sense of hope for a union between different minds within the material world, which corresponded to his early, idealistic sense of science as a mental vehicle for making one's way through the material world. When Southey began to consider matter more intently and personally, however, his sense of hope's relationship to matter would shift.

\section{Materialist Craving in The Curse of Kehama}

19. In Southey's 1810 poem, the rajah Kehama curses Ladurlad after Ladurlad has killed Kehama's son, Arvalan (Ladurlad has done this in order to protect his daughter Kailyal from Arvalan). Kehama's curse upon Ladurlad is specifically material and isolating. Kehama says that "the Winds shall not touch thee / When they pass by thee, / And the Dews shall not wet thee" (II.156-158). "Thee, thee, thee": the self-rhymes emphasize the isolation of "thee," the repeated "thee"-ness of thee, cut off from everything else - from the kind of winds and dews that Davy had described in his poetry. This lonely material existence recalls the abnormal response Southey saw in his own experiences of nitrous oxide. Kehama's curse, then, is Southey's version of a pneumatic chemist's curse: Ladurlad will be stuck with his own, idiosyncratically unsatisfying experience of atmosphere, and he will begin to thirst for more from the material world.

20. In a comic book, this "curse" might almost immediately be treated as a superpower, but Ladurlad suffers from it, often because of how it isolates him. "He staggers from the dreadful spot; the throng / Give way in fear before him; / Like one who carries pestilence" (III.20-22). Ladurlad reflects that Kehama,

Hath sent a fire into my heart and brain, 
A burning fire, for ever there to be!

The winds of Heaven must never breathe on me;

The rains and dews must never fall on me;

Water must mock my thirst and shrink from me (III.117-121)

Notice the self-rhyming of selfhood here: me, me, me - in total, "me" will be rhymed with itself six times in this section (III.119-124), recalling the rhymes of Kehama's original curse that links thee with thee with thee. An obsessive self-focus gets reinforced, but it happens specifically in language of repeated thirsting - a condition suggestive of what we might now call addiction, all owing to a cursed inability to merge comfortably or typically with matter.

21. Elsewhere, Southey also links thirst with the struggle to breathe comfortably. This occurs in the notes to The Curse of Kehama, specifically those for Book Four. Southey describes the "tufted lark" and how one "may see these birds, as well as sparrows, in the middle of the day, with their bills half open, and the muscles of their breasts agitated, breathing with difficulty, and as if they panted for respiration"; this instinct to suffer for the sake of living some preferred life, Southey editorializes, "resembles the mind of man, whom a thirst for riches engages to brave calamities" (EPW 201). Mind, desire, physical struggle, and thirst coincide here, represented by the figure of the bird laboring to breathe. Southey associates that awkward respiration with craving and with "the mind of man" more generally.

22. The scenic lines that Southey glosses with his description of the tufted lark (IV.18-19) demonstrate, moreover, how the mind can poetically react to vexing material circumstances. Here is that passage:

But now the Sun in heaven is high,

The little songsters of the sky

Sit silent in the sultry hour,

They pant and palpitate with heat;

Their bills are open languidly

To catch the passing air;

They hear it not, they feel it not,

It murmurs not, it moves not. (IV.18-24)

An intensely repetitive condition of wanting emerges from oppressive material experience, and while the deprivation faced by the birds leads them to remain silent, the poet generates a 


\section{Romanticism on the Net \#68-69 (Spring-Fall 2017). Special issue on Robert Southey. Guest-edited by Tim Fulford (De Montfort University) and Matthew Sangster (University of Glasgow)}

compensatory song - a sonically, materially repetitive passage-from this scene. The alliterative expression of the panting and palpitation performed by those songsters sitting in silence matches their physical, materially repetitive state, giving voice to their otherwise silently embodied condition of deprivation and yearning. Thus poetry emerges from a thwarted desire that is itself mired in materiality.

23. Soon Ladurlad's repeated experience of that which cannot be satisfactorily, materially attained also lends to him poetic, imaginative capabilities - he does not just get frozen in a miserably cursed state, he starts doing things, imaginatively, with his curse. "Musing so long he lay, that all things seem / Unreal to his sense, even like a dream, / A monstrous dream of things which could not be" (IV.43-45). Without familiarly satisfying material experience, Ladurlad might at first think and behave like the tufted lark, static and briefly without song-yet he has the capacity to imagine that which is estranged, to cast his thoughts to different perspectives from which he might contemplate his condition. While "all the morning was Ladurlad laid, / Silent and motionless," he was also "pondering with steady mind, / As if it were another's Curse, / His own portentous lot" (IV.29-35). Ladurlad considers himself as if he were another; his point of view shifts about in the new imaginative space opened up by the absence of familiar physicality, and he briefly allows himself a third-person point of view of first-person reality.

24. Part of Ladurlad's imaginative capability here owes to the fact that he maintains his cool, relatively-Southey writes that Ladurlad, while static, was not only working "with steady mind" but also acting "like one at ease" (IV.30). We see, then, in the case of Ladurlad something like the poetic strength other Romantics located in indolence. Yet for Keats, indolence represents a state apart from "the voice of busy common-sense" ("Ode on Indolence" 40), and for Coleridge, such indolent moments could occur also within the shelter of the limetree bower from which a steadily imaginative reconciliation between mind and nature can be achieved. In “This Lime-Tree Bower My Prison," Coleridge writes, "No plot so narrow, be but Nature there, / No waste so vacant, but may well employ / Each faculty of sense" (61-63). In The Curse of Kehama, a condition of easefulness, amid matter whose meaning and effects shift, generally proves rather less untroubled, if still intellectually useful.

25. Again, after his experiences with nitrous oxide, Coleridge maintained a hopeful attitude toward the links between the imagination and nature that could arise from a state of indolence. In 


\section{Romanticism on the Net \#68-69 (Spring-Fall 2017). Special issue on Robert Southey. Guest-edited by Tim Fulford (De Montfort University) and Matthew Sangster (University of Glasgow)}

"Fancy in Nubibus, Or the Poet in the Clouds," Coleridge writes that "it is pleasant, with a heart at ease ... [t]o make the shifting clouds be what you please" (1-3). The mind can alter physical matter as it pleases, according to enjoyment, and such enjoyments can occur in an indolent moment. That which the speaker in the lime-tree bower lacks, detached from friends, fails to be much of a problem; in the poem, the speaker reflects on how one might "a traveller, go / From mount to mount through Cloudland, gorgeous land" (8-9). Limited perspective allows for a greater expanse of imaginative wandering. Southey, too, describes a compensatory poetic power in moments of lack or deprivation, but he is also less philosophical about such deprivations, and he voices concerns about the material ramifications, implications, and substrate of such deprivation.

26. This agitated, imaginative condition brought about by deprivation and craving-even among the relatively indolent - propels in The Curse of Kehama an empiricist, scientific investigation. Ladurlad attempts to test out his state. He formulates a question, a kind of hypothesis, and then experiments:

Is it indeed a dream? He rose to try,

Impatient to the water-side he went,

And down he bent,

And in the stream he plung'd his hasty arm

To break the visionary charm. (IV.55-59)

Ladurlad does not succeed at breaking the visionary charm, but he studies it nonetheless. "For the Water knew Kehama's charm, / The Water shrunk before his arm. / His dry hand moved about unmoisten'd there" (IV.64-66). Ladurlad's material actuality corresponds here with what he considers a possible dream. His sense that he cannot adequately interact with matter is both dreamily magical and materially demonstrable.

27. This sense of matter, while fantastical, resembles an intensified version of the thinking about matter found in the writings of those who had engaged in pneumatic studies. For someone like Davy, matter would link everything together yet still suggest or inspire hopes for something more, leading him to aspire toward "something which posterity may own" (Baillie 161). The cursed or charmed Ladurlad represents something along these lines - a subjectively charged scientific sensibility - by dreaming, figuring all things as monstrous, and then testing those things out in a way that brings him more consciously into a relationship with a material reality 


\section{Romanticism on the Net \#68-69 (Spring-Fall 2017). Special issue on Robert Southey. Guest-edited by Tim Fulford (De Montfort University) and Matthew Sangster (University of Glasgow)}

that leads him to further imaginative responses. Kehama's curse, meanwhile, ultimately reverses onto Kehama himself when he is condemned by the poem's end and turned into a statue for having been a "fool of drunken hope" who has sought "for power beyond" his "scope / Of knowledge" (XXIV.205-207). Ladurlad experiences such hopeful cravings more thoughtfully, as he tests and experiments his way through his condition.

28. The curse upon Ladurlad does empower him at times, such as when he dives into the water to save his daughter: "The water knew Kehama's spell, / The water shrunk before him" (III.5758). Because matter does not affect him so directly, he can act upon matter with greater agency. Ladurlad's condition allows him to think about matter from some distance, with a strategy more sensitively thoughtful than Kehama's tyrannical approach. There is also still some range of perception available to Ladurlad to compensate for the ways in which his sensations have been reduced. When " $[\mathrm{t}]$ he night-wind is abroad, / Aloft it moves among the stirring trees," Ladurlad, we are told, "only heard the breeze," but at least he can still sense the breeze in some way (V.112-114). The sonic evocations of all that Ladurlad misses remain, and Ladurlad is thoughtful enough to attend to those evocations. The poetic representation of the world of sonorous sensation flourishes, then, and the intimations of that which Southey will convey at greater length in prose - such as the descriptions he quotes of weather in India - are present in these lines, too.

29. Ladurlad thus has a poetic and intellectual capacity specifically phrased in pneumatic terms, intensified due to the intensified nature of his incomplete relationship with materiality. Craving, embodied hope for more than what is directs him toward poetic, intellectual work. As Madeleine Callaghan has written, Kehama's "reign seems to extend not only over physical dominion, but over language itself' (39), and Ladurlad's nature is shaped by Kehama's reign. The movement he displays between the physical and the linguistic, structured by a thirstily imaginative pursuit of material possibilities, would appeal to later Romantics too. Michael O'Neill has described Shelley's appreciation of Southey's poetry, especially The Curse of Kehama and Thalaba the Destroyer, and he suggests that "Shelley heard in Southey's rhythmic measures impulses towards freedom" (15). O'Neill writes that "Shelley's rhythmic energy, with its strong forward-leaning, anticipatory bias, is at once his own and an advanced, more ideologically dynamised version of Southey's implicitly millenarian cadences" (16). This shared anticipatory quality can be seen clearly if we compare the effects of Kehama's curse to 
Shelley's work, as O'Neill does (see, for instance, O'Neill 22-23), because Kehama's curse does nothing if it does not instill in Ladurlad a sense of craving, which then empowers Ladurlad poetically and otherwise to think and behave with a greater, thoughtful sense of anticipation.

30. One other aspect of Southey's verse that O'Neill cites as influential for Shelley is the variation of meter. As O'Neill explains, Shelley had claimed Thalaba the Destroyer as an influence for the "singularity" of his own work (qtd. in O'Neill 15) and Francis Jeffrey identified as especially singular Southey's irregular verse's “jumble” (qtd. in O'Neill 16). This jumble of meters speaks to something others have noted: Southey's poetic tendency toward prose, or mixture of poetry and prose. This can be seen even at the level of the copious notes he includes with The Curse of Kehama, notes often intimated or explicitly marked at moments when the poem's material descriptions promise more than they can fully reveal. Southey himself regarded such rhythms and scattered rhymes in terms of a particular kind of material experience. He had sought to create poetry that could affect the reader materially, leaving one "half dozing with the thundering echo," and he had found similarly material experiences in his pneumatic experiments to be variable, discomfiting, and complicated. He had come to know of material experience that can be alternately thrilling and uncomfortable, experience marked by the rhythms of craving for something more in a complexly volatile material reality. 


\section{Romanticism on the Net \#68-69 (Spring-Fall 2017). Special issue on Robert Southey. Guest-edited by Tim Fulford (De Montfort University) and Matthew Sangster (University of Glasgow)}

\section{Works Cited}

Baillie, Joanna, editor. A Collection of Poems, Chiefly Manuscript, and from Living Authors. London: Longman, 1823.

Brantlinger, Patrick. Rule of Darkness: British Literature and Imperialism, 1830-1914. Ithaca: Cornell University Press, 1988.

Callaghan, Madeleine. “The Poetics of Perception in Southey's The Curse of Kehama and Byron's The Giaour." Wordsworth Circle, vol. 42, no. 1, 2011, pp. 38-41.

Coleridge, Samuel Taylor. Collected Letters of Samuel Taylor Coleridge. 6 vols., edited by Earl Leslie Griggs, Oxford: Clarendon Press, 1956-71. (Letters).

---. The Complete Poems. Edited by William Keach, New York: Penguin, 1997.

Davy, John. Memoirs of the Life of Sir Humphry Davy. London: Smith, Elder and Co., 1839.

Fulford, Tim. "Pagodas and Pregnant Throes: Orientalism, Millenarianism and Robert Southey." Romanticism and Millenarianism, edited by Tim Fulford, New York: Palgrave, 2002.

Jay, Mike. The Atmosphere of Heaven: The Unnatural Experiments of Dr Beddoes and His Sons of Genius. New Haven: Yale University Press, 2009.

Jeffrey, Francis. "Unsigned review of Thalaba." Robert Southey: The Critical Heritage, edited by Lionel Madden, London: Routledge, 1995, pp. 68-90.

Keats, John. The Poems of John Keats. Edited by Jack Stillinger, Cambridge, MA: Belknap Press, 1978.

Leask, Nigel. British Romantic Writers and the East: Anxieties of Empire. Cambridge: Cambridge University Press, 2004.

Levere, Trevor. "Chemistry, Consumption, and Reform." The Enlightenment of Thomas Beddoes:

Science, Medicine, and Reform, edited by Trevor Levere et al., New York: Routledge, 2017.

O’Neill, Michael. "Southey and Shelley Reconsidered.” Romanticism, vol. 17, no. 1, 2011, pp. 10-24.

Porter, Dahlia. "Formal Relocations: The Method of Southey's Thalaba the Destroyer (1801)." European Romantic Review, vol. 20, no. 5, 2009, pp. 671-679.

Rajan, Balachandra. "Monstrous Mythologies: Southey and The Curse of Kehama." European Romantic Review, vol. 9, no. 2, 1998, pp. 201-216.

Ruston, Sharon. "From 'The Life of the Spinosist' to 'Life': Humphry Davy, Chemist and Poet." Literature and Chemistry, edited by Margareth Hagen and Margery Skagens, Aarhus: Aarhus University Press, 2014, pp. 77-97. 
Romanticism on the Net \#68-69 (Spring-Fall 2017). Special issue on Robert Southey. Guest-edited by Tim Fulford (De Montfort University) and Matthew Sangster (University of Glasgow)

Southey, Robert. The Collected Letters of Robert Southey: A Romantic Circles Electronic Edition, general editors Lynda Pratt, Tim Fulford, and Ian Packer, University of Maryland: Romantic Circles Electronic Editions, 2009-, http://www.rc.umd.edu/editions/southey_letters. (CLRS).

---. The Curse of Kehama. Poetical Works 1793-1810: Volume 4, edited by Daniel Sanjiv Roberts, London: Pickering and Chatto, 2004. (EPW).

---. Letters from England, by Don Manuel Alvarez Espriella. Vol. 2, Philadelphia: Benjamin Warner, 1818. 
${ }^{1}$ Francis Jeffrey was just one reader who noticed in Southey's poetry something closer to prose; he wrote in his review of Thalaba the Destroyer about the "singular structure" of the poem, which included "a jumble of all the measures that are known in English" (78).

${ }^{2}$ That calmer sense of hope that could sustain experience of material reality would persist in the work of Coleridge, however. In his sonnet "Work Without Hope," from the 1820s (Complete Poems 383), Coleridge describes material nature existing with a sense of vital hope and forward-thinking activity. "Slugs leave their lair" (1) while "bees are stirring" (2) and "birds are on the wing" (2), Coleridge writes; he concludes, "Work without Hope draws nectar in a sieve, / And Hope without an object cannot live" (13-14). Here, hope and matter must either coexist or vanish into deathly stasis; the point is that a happily sustained hope might exist in material existence, while a simply abstract hope cannot last. The despondent speaker of the poem, lost in thoughts detached from material goals, is "the sole unbusy thing" (5) for whom flowers "bloom not" (10). This is a relatively neat formulation of a relationship between hope and vital matter. 